\section{Response of Highbush Blueberry to Nitrogen Fertilizer During Field Establishment, I: Accumulation and Allocation of Fertilizer Nitrogen and Biomass}

\author{
M. Pilar Bañados ${ }^{1}$ \\ Departmento de Fruiticultura y Enologia, Pontificia Universidad Católica de \\ Chile, Casilla 306-22, Santiago, Chile
}

Bernadine C. Strik ${ }^{2,3}$

Department of Horticulture, Oregon State University, 4017 ALS, Corvallis, OR 97331

\begin{abstract}
David R. Bryla
U.S. Department of Agriculture, Agricultural Research Service, Horticultural Crops Research Unit, 3420 NW Orchard Avenue, Corvallis, OR 97330
\end{abstract}

Timothy L. Righetti

University of Guam, UOG Station, Mangilao, Guam 96923

Additional index words. Vaccinium corymbosum, nitrogen partitioning, yield, fertilization, ${ }^{15} \mathrm{~N}$, ammonium, translocation, dry matter, reserve $\mathrm{N}$, nitrogen removal, nitrogen use efficiency, soil N

\begin{abstract}
The effects of nitrogen (N) fertilizer application on plant growth, $\mathrm{N}$ uptake, and biomass and $\mathrm{N}$ allocation in highbush blueberry (Vaccinium corymbosum L. 'Bluecrop') were determined during the first 2 years of field establishment. Plants were either grown without $N$ fertilizer after planting $(0 N)$ or were fertilized with 50,100 , or $150 \mathrm{~kg} \cdot \mathrm{ha}^{-1}$ of $N$ $\left(50 \mathrm{~N}, 100 \mathrm{~N}, 150 \mathrm{~N}\right.$, respectively) per year using ${ }^{15} \mathrm{~N}$-depleted ammonium sulfate the first year (2002) and non-labeled ammonium sulfate the second year (2003) and were destructively harvested on 11 dates from Mar. 2002 to Jan. 2004. Application of 50N produced the most growth and yield among the $\mathbf{N}$ fertilizer treatments, whereas application of $100 \mathrm{~N}$ and $150 \mathrm{~N}$ reduced total plant dry weight (DW) and relative uptake of $\mathrm{N}$ fertilizer and resulted in $17 \%$ to $55 \%$ plant mortality. By the end of the first growing season in Oct. 2002, plants fertilized with $50 \mathrm{~N}, 100 \mathrm{~N}$, and $150 \mathrm{~N}$ recovered $17 \%, 10 \%$, and $3 \%$ of the total $N$ applied, respectively. The top-to-root $D W$ ratio was $1.2,1.6,2.1$, and 1.5 for the $0 \mathrm{~N}, 50 \mathrm{~N}, 100 \mathrm{~N}$, and $150 \mathrm{~N}$ treatments, respectively. By Feb. 2003, $0 \mathrm{~N}$ plants gained $1.6 \mathrm{~g} /$ plant of $\mathrm{N}$ from soil and pre-plant $\mathrm{N}$ sources, whereas fertilized plants accumulated only $0.9 \mathrm{~g} /$ plant of $\mathrm{N}$ from these sources and took up an average of $1.4 \mathrm{~g} / \mathrm{plant}$ of $\mathrm{N}$ from the fertilizer. In Year 2, total $\mathrm{N}$ and dry matter increased from harvest to dormancy in $\mathrm{ON}$ plants but decreased in $\mathrm{N}$-fertilized plants. Plants grown with $0 \mathrm{~N}$ also allocated less biomass to leaves and fruit than fertilized plants and therefore lost less DW and $\mathrm{N}$ during leaf abscission, pruning, and fruit harvest. Consequently, by Jan. 2004, there was little difference in $\mathrm{DW}$ between $0 \mathrm{~N}$ and $50 \mathrm{~N}$ treatments; however, as a result of lower $\mathrm{N}$ concentrations, $0 \mathrm{~N}$ plants accumulated only $3.6 \mathrm{~g} /$ plant $\left(9.6 \mathrm{~kg} \cdot \mathrm{ha}^{-1}\right)$ of $\mathrm{N}$, whereas plants fertilized with $50 \mathrm{~N}$ accumulated $6.4 \mathrm{~g} /$ plant $\left(17.8 \mathrm{~kg} \cdot \mathrm{ha}^{-1}\right), 20 \%$ of which came from ${ }^{15} \mathrm{~N}$ fertilizer applied in 2002. Although fertilizer $N$ applied in 2002 was diluted by nonlabeled $N$ applications the next year, total $N$ derived from the fertilizer (NDFF) almost doubled during the second season, before post-harvest losses brought it back to the starting point.
\end{abstract}

Highbush blueberry (Vaccinium sp.) area in North America has increased from 27,105 ha in 2003 to 38,690 ha in 2008 , a rate of 2,317 ha/year (Brazelton, 2009; Strik and Yarborough, 2005). Blueberry production worldwide has increased $82 \%$ in the same time period to 65,990 ha in 2008 , a planting rate of 5,950 ha/year (Brazelton, 2009; Brazelton and Strik, 2007). To these fields, growers have generally been applying recommended rates
In a 5-year study on 'Bluecrop' blueberry, plants fertilized with a split application of 75 $\mathrm{kg} \cdot \mathrm{ha}^{-1}$ of $\mathrm{N}$ had higher yields than unfertilized controls (Hanson and Retamales, 1992). In contrast, Clark et al. (1998) found that yield of 'Collins' blueberry was unaffected by fertilization rates of 22 and $112 \mathrm{~kg} \cdot \mathrm{ha}^{-1}$ of $\mathrm{N}$, and in fact, applications of 67 and 134 $\mathrm{kg} \cdot \mathrm{ha}^{-1}$ reduced yield compared with 22 $\mathrm{kg} \cdot \mathrm{ha}^{-1}$ of $\mathrm{N}$ over 2 years. In an 8 -year study, Cummings (1978) found that yield was not increased at $\mathrm{N}$ fertilization rates above the lowest rate of $34 \mathrm{~kg} \cdot \mathrm{ha}^{-1}$.

Throop and Hanson (1997) showed that mature blueberry plants absorbed fertilizer $\mathrm{N}$ most efficiently during active growth between late bloom and fruit maturity; however, only $8 \%$ of the fertilizer was recovered 2 weeks after application. Mature 'Bluecrop' plants fertilized with $40 \mathrm{~kg} \cdot \mathrm{ha}^{-1}$ of N, as urea, before budbreak recovered a much greater proportion $(32 \%)$ of the fertilizer $\mathrm{N}$ by the next fall (Retamales and Hanson, 1989). These studies suggest that multiple applications of fertilizer $\mathrm{N}$ are necessary to maintain sufficient soil $\mathrm{N}$ levels throughout the active growth period of blueberry.

No work has been published to date on $\mathrm{N}$ fertilizer uptake and partitioning in young, field-grown blueberry plants. The objectives of our study were to determine the impact of $\mathrm{N}$ fertilizer application on $\mathrm{N}$ uptake, allocation, and growth of young, field-grown blueberry plants during the first 2 years of establishment.

\section{Materials and Methods}

A planting of 'Bluecrop' blueberry was established on 27 Mar. 2002 at the North Willamette Research and Extension Center in Aurora, OR (long. $45^{\circ} 17^{\prime} \mathrm{N}$, lat. $122^{\circ} 45^{\prime} \mathrm{W}$; $46 \mathrm{~m}$ above sea level; last spring freeze occurs on 17 Apr., on average, and first fall freeze occurs on 25 Oct.). Plants were spaced at $1.2 \mathrm{~m}$ in the row with $3.0 \mathrm{~m}$ between rows ( 2777 plants/ha) on Quatama series soil (fineloamy, mixed, mesic Aqualtic Haploxeralfs). Douglas fir (Pseudotsuga menziesii Franco) sawdust, $0.2 \mathrm{~m}$ deep and $0.3 \mathrm{~m}$ wide centered on planting rows, and fertilizer (66 $\mathrm{kg} \cdot \mathrm{ha}^{-1}$ of $\mathrm{N}$ as ammonium sulfate), a standard commercial practice when adding fresh organic matter, were incorporated in the soil before planting 2-year-old container-grown stock (4-L pots). No surface sawdust mulch was applied after planting. Flower buds were pruned off the plants at planting to prevent fruit production in the first growing season (2002). Plants were pruned in Winter 2002-2003 per standard commercial practice and prunings removed from the field.

The fertilizer treatments after planting were: no additional fertilizer $\mathrm{N}(0 \mathrm{~N})$ in $2002-$ 2003; and three rates of $\mathrm{N}, 18.6,37.2$, or 55.8 $\mathrm{g} /$ plant per year (equivalent to 50,100 , or 150 $\mathrm{kg} \mathrm{N} / \mathrm{ha}, 50 \mathrm{~N}, 100 \mathrm{~N}, 150 \mathrm{~N}$, respectively) in 2002 and 2003. The total rate of $\mathrm{N}$ was divided into thirds and applied on 11 Apr., 20 May, and 27 June 2002 of the planting year and on 24 Mar., 8 May, and 23 June 2003 in Year 2 at the 
same rate. Labeled ${ }^{15} \mathrm{~N}$-depleted ammonium sulfate $\left[\left(\mathrm{NH}_{4}\right)_{2} \mathrm{SO}_{4}\right]$ was applied in 2002 and unlabeled ammonium sulfate was applied in 2003. Fertilizer was broadcast on the soil surface under the plant canopy in a circular area. All treated plots were fertilized with 35 $\mathrm{kg} \cdot \mathrm{ha}^{-1}$ of phosphorus as triple superphosphate and $66 \mathrm{~kg} \cdot \mathrm{ha}^{-1}$ of potassium as potassium sulfate each spring. Plants were irrigated with an overhead system and were otherwise maintained according to standard commercial practice (Strik et al., 1993).

The experimental treatments were arranged in a randomized complete block design with three replicates. The experimental unit consisted of a plot of 12 plants. One plant per plot was randomly selected and destructively harvested on each of 11 dates: 27 Mar., 29 Apr., 7 June, 24 July, and 29 Oct. 2002; 7 Feb., 22 Apr., 22 May, 25 July, and 27 Oct. 2003; and 8 Jan. 2004. Plants were dug from the field to a depth of $0.30-0.45 \mathrm{~m}$ to recover as much of the root system as possible. Roots were washed with high-pressure water to remove soil, and plants were separated into the following parts: flowers and fruit (2003 only), new shoots, leaves (removed from shoots), woody canes, crown, and roots. Leaves collected in late October of each year were considered to be at or near time of abscission based on field observations. In this study, plants dug in late October were considered to be at the end of the growing season.

Each part was oven-dried at $70{ }^{\circ} \mathrm{C}$, to a constant weight, and dry weight was measured. A subsample of each tissue was ground to pass a 40 -mesh screen (0.42-mm openings) and measured for total $\mathrm{N}$ and ${ }^{15} \mathrm{~N}$ concentrations by mass spectrometry (Isotope Service, Los Alamos, NM).

Soil samples were collected from the potting medium of nursery plants before planting and the rooting zone of harvested plants on each date at a depth of $\approx 0.15-0.40 \mathrm{~m}$. Soil samples were analyzed for $\mathrm{pH}$, total $\mathrm{N}, \mathrm{NH}_{4}{ }^{+}$, $\mathrm{NO}_{3}{ }^{-}$, and ${ }^{15} \mathrm{~N}$ concentrations (Central Analytical Laboratory, Oregon State Univ., Corvallis, OR) from Sept. 2002 through Jan. 2004, except for ${ }^{15} \mathrm{~N}$ for which samples ended May 2003.

Atom percent values were converted to the proportion of NDFF using standard conversions (Hauck and Bremner, 1976): \%NDFF = $\left[\left({ }^{15} \mathrm{~N}\right.\right.$ natural abundance $)-\left(\right.$ atom $\left.\left.\%{ }^{15} \mathrm{~N}_{\text {sample }}\right)\right] /$ $\left[\left({ }^{15} \mathrm{~N}\right.\right.$ natural abundance $)-\left(\right.$ atom $\left.\left.\%{ }^{15} \mathrm{~N}_{\text {fertilizer }}\right)\right]$ $\times 100$. The ${ }^{15} \mathrm{~N}$ natural abundance was assumed equal to 0.366 atom percent.

Received for publication 18 Jan. 2012. Accepted for publication 3 Mar. 2012.

Mention of a trademark, proprietary product, or vendor does not constitute a guarantee or warranty of the product by the U.S. Dept. of Agriculture or Oregon State University and does not imply its approval to the exclusion of other products or vendors that also may be suitable.

${ }^{1}$ Former $\mathrm{PhD}$ graduate student, Department of Horticulture, Oregon State University.

${ }^{2}$ Professor.

${ }^{3}$ To whom reprint requests should be addressed; e-mailstrikb@hort.oregonstate.edu.
The effect of $\mathrm{N}$ fertilizer rate and sampling date on each measured variable was analyzed using the PROC MIXED procedure in SAS Version 9.1 (SAS Institute Inc., Cary, NC). Partitioning of DW and N among plant parts was expressed as a percentage of the plant total and arcsine transformed before analysis. Back-transformed values are presented in figures and tables. Plant response to $\mathrm{N}$ fertilizer application rate was determined using orthogonal contrasts and pairwise comparisons.

\section{Results and Discussion}

Plant growth. Nitrogen fertilizer application rate ( $\mathrm{N}$ rate) significantly affected plant DW over time $(P<0.0001)$ (Fig. 1A). In the first growing season, total DW increased rapidly from budbreak in April to onset of leaf abscission in Oct. 2002. Plants fertilized with $50 \mathrm{~N}$ had the greatest DW at the end of the first growing season $(0.36 \mathrm{~kg} /$ plant $)$, whereas $150 \mathrm{~N}$ plants had the least growth.

Plants fertilized with $100 \mathrm{~N}$ and $150 \mathrm{~N}$ showed symptoms of salt stress (e.g., interveinal chlorosis and marginal leaf necrosis in young developing leaves; Caruso and Ramsdell, 1995) in Year 1 with 17\% and 55\% of the plants dying by Oct. 2002, respectively. Cummings (1978) likewise observed 23\% mortality in 4-year-old highbush blueberry plants fertilized with $168 \mathrm{~kg} \cdot \mathrm{ha}^{-1}$ of $\mathrm{N}$ in North Carolina. In both cases, ammoniumbased fertilizers were used, which are often recommended for blueberry because 1) the plants prefer the $\mathrm{NH}_{4}{ }^{+}$form of $\mathrm{N}$ over $\mathrm{NO}_{3}{ }^{-}$; and 2) the fertilizers are acidifying, and blueberry plants grow best when soil $\mathrm{pH}$ is
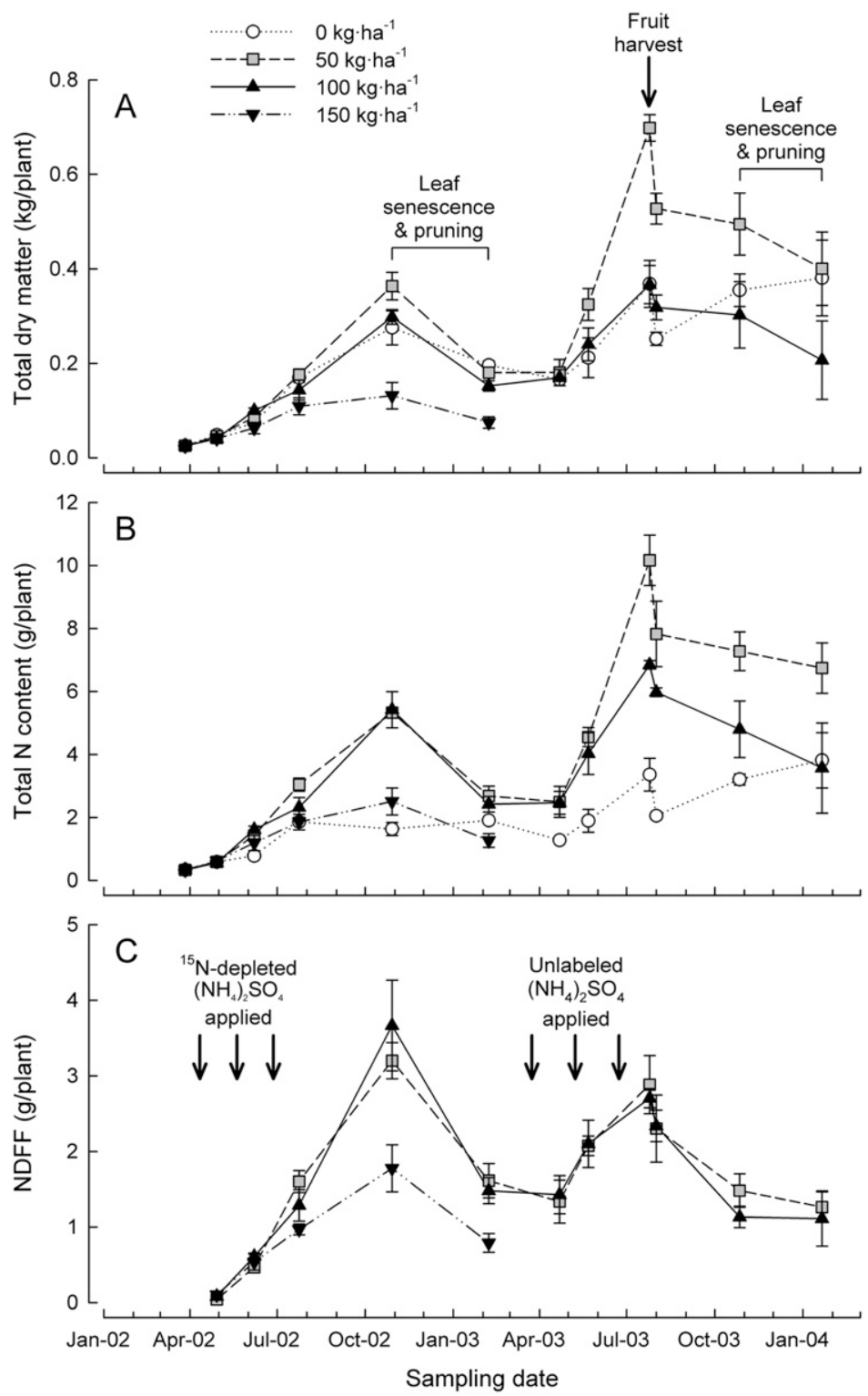

Fig. 1. Total dry matter $(\mathbf{A})$, total nitrogen $(\mathrm{N})$ content $(\mathbf{B})$, and $\mathrm{N}$ derived from fertilizer (NDFF) $(\mathbf{C})$ in young plants of 'Bluecrop' blueberry. Plants were established on 27 Mar. 2002 and left unfertilized after planting (0) or fertilized each spring with 50,100 , or $150 \mathrm{~kg} \cdot \mathrm{ha}^{-1}$ of $\mathrm{N}$. Time of natural leaf senescence, manual pruning, and fruit removal indicated in $\mathbf{A}$ and fertilizer application indicated in $\mathbf{C}$. NDFF represents labeled $\mathrm{N}$ applied during the first year after planting and does not include any $\mathrm{N}$ applied the next year. Each symbol represents the mean of three replicates and error bars represent \pm 1 SE. 
between 4.2 and 5.5 (Eck, 1988; Korcak, 1988; Poonnachit and Darnell, 2004); however, these fertilizers are very rapidly absorbed and also have a high salt index and therefore often lead to salinity problems in many plants, including blueberry, when overapplied (Ludwick, 1998). Bryla and Machado (2011) observed that electrical conductivity (EC) of soil solution under young blueberry plants reached levels as high as $4 \mathrm{dS} \cdot \mathrm{m}^{-1}$ when ammonium sulfate was applied at a rate of $50 \mathrm{~kg} \cdot \mathrm{ha}^{-1}$ of $\mathrm{N}$ and up to $5-8 \mathrm{dS} \cdot \mathrm{m}^{-1}$ when applied at a rate of $100-150 \mathrm{~kg} \cdot \mathrm{ha}^{-1}$ of $\mathrm{N}$. In our study, we did not measure soil EC, but it is known that blueberry is considered sensitive to EC greater than 1.5-2.0 dS. $\mathrm{m}^{-1}$ (Patten et al., 1988). In contrast, young 'Star' southern highbush blueberry plants grown in pine bark had increased plant growth and yield with $\mathrm{N}$ rates as high as $50-81 \mathrm{~g} /$ plant or 360 $580 \mathrm{~kg} \cdot \mathrm{ha}^{-1}$ of $\mathrm{N}$ (Williamson and Miller, 2009). In this case, plants were at a much higher density (7176 plants/ha) than in our study, and fertilizer was applied gradually every 4 weeks from April to August or every 2 weeks by fertigation. Plant-available $\mathrm{N}$ was also likely much lower in the pine bark culture system. In our study, plants that survived at the highest $\mathrm{N}$ rate in 2002 had essentially no growth in 2003.

The top-to-root DW ratio in Oct. 2002, at the end of the first growing season, was 1.2, $1.6,2.1$, and 1.5 for the $0 \mathrm{~N}, 50 \mathrm{~N}, 100 \mathrm{~N}$, and $150 \mathrm{~N}$ treatments, respectively (data not shown). Unfertilized plants had a lower DW of leaves and shoots than those fertilized with $50 \mathrm{~N}$. Plants fertilized with $150 \mathrm{~N}$ had a lower total plant DW as a result of less weight in all plant parts.

Over winter, total DW decreased from Oct. 2002 to Feb. 2003 as a result of leaf abscission and removal of wood during pruning (Fig. 1A). After pruning in Winter 20022003, there was no difference in plant DW among the $0 \mathrm{~N}, 50 \mathrm{~N}$, and $100 \mathrm{~N}$ treatments nor was there an effect on percent allocation of DW to plant parts. However, $0 \mathrm{~N}$ and $50 \mathrm{~N}$ plants had greater root DW (average of $99 \mathrm{~g}$; $P<0.0001)$ in Feb. 2003 than $100 \mathrm{~N}$ plants $(82 \mathrm{~g})$ or $150 \mathrm{~N}$ plants $(33 \mathrm{~g})$. Plants fertilized with $50 \mathrm{~N}$ had the greatest increase in DW in Year 2 from budbreak in Apr. 2003 to fruit harvest in July. Fruit DW at harvest averaged $0.12,0.17$, and $0.05 \mathrm{~kg} /$ plant for the $0 \mathrm{~N}, 50 \mathrm{~N}$, and $100 \mathrm{~N}$ treatments, respectively. In each treatment, plant DW reached a maximum at harvest. Plants fertilized with $50 \mathrm{~N}$ had a total yield of $2.6 \mathrm{t} \cdot \mathrm{ha}^{-1}$ of fresh fruit, a high yield for the second growing season, and greater than the yield of the $0 \mathrm{~N}$ and $100 \mathrm{~N}$ treatment plants (1.9 and $0.8 \mathrm{t} \cdot \mathrm{ha}^{-1}$, respectively). Higher rates of $\mathrm{N}$ fertilization have also reduced yield of young plants in other studies (Cummings, 1978).

By the end of the second growing season, differences in total DW among treatments were reduced after leaf abscission in late October, although plants fertilized with $50 \mathrm{~N}$ still had significantly more total DW than the $0 \mathrm{~N}$ and $100 \mathrm{~N}$ plants $(P<0.0001)$; however, there was no difference in DW or allocation of DW among plant parts between the $50 \mathrm{~N}$ and $0 \mathrm{~N}$ treatments by the beginning of Year 3 , mostly a result of less pruning or wood removal in plants grown without additional fertilizer $(0 \mathrm{~N}$; data not shown). There was a trend $(P=0.08)$ for $100 \mathrm{~N}$ plants to have less root DW (73 g) than $0 \mathrm{~N}(158 \mathrm{~g})$ or $50 \mathrm{~N}$ (151 g) plants in Jan. 2003.

Biomass per hectare (2777 plants/ha) in plants fertilized with $50 \mathrm{~N}$ increased from 71 $\mathrm{kg} \cdot \mathrm{ha}^{-1}$ in Mar. 2002 to a maximum of 1940 $\mathrm{kg} \cdot \mathrm{ha}^{-1}$ in July 2003 and a final biomass of $1112 \mathrm{~kg} \cdot \mathrm{ha}^{-1} \mathrm{DW}$ by the end of the study in Jan. 2004. In comparison, $0 \mathrm{~N}$ plants had a final biomass of $1057 \mathrm{~kg} \cdot \mathrm{ha}^{-1}$ DW (Fig. 1A).

Table 1. Dry weight allocation among different parts of young 'Bluecrop' blueberries during the first 2 years after planting. ${ }^{\mathrm{z}}$

\begin{tabular}{|c|c|c|c|c|c|c|c|c|c|}
\hline \multirow[b]{3}{*}{ Sample date } & \multicolumn{9}{|c|}{ Dry wt allocation (\%) } \\
\hline & \multirow[b]{2}{*}{$\begin{array}{l}\mathrm{N} \text { fertilizer } \\
\left(\mathrm{kg} \cdot \mathrm{ha}^{-1}\right)\end{array}$} & \multirow[b]{2}{*}{ Leaves } & \multirow[b]{2}{*}{$\begin{array}{l}\text { New } \\
\text { shoots }\end{array}$} & \multirow[b]{2}{*}{ Flowers/fruit } & \multicolumn{3}{|c|}{ Woody canes } & \multirow[b]{2}{*}{ Crown } & \multirow[b]{2}{*}{ Roots } \\
\hline & & & & & $\begin{array}{c}1 \text { year } \\
\text { old }\end{array}$ & $\begin{array}{l}2 \text { years } \\
\text { old }\end{array}$ & $\begin{array}{c}3 \text { years } \\
\text { old }\end{array}$ & & \\
\hline 27 Mar. 2002 & - & - & - & - & 65.5 & - & - & - & $\overline{34.5}$ \\
\hline \multirow[t]{5}{*}{29 Apr. 2002} & 0 & - & 8.0 & - & 45.3 & - & - & 7.9 & 38.8 \\
\hline & 50 & - & 8.7 & - & 38.6 & - & - & 7.8 & 44.8 \\
\hline & 100 & - & 11.5 & - & 51.0 & - & - & 11.8 & 25.7 \\
\hline & 150 & - & 6.7 & - & 41.3 & - & - & 8.9 & 43.0 \\
\hline & Significance ${ }^{w}$ & & NS & & NS & & & NS & NS \\
\hline \multirow[t]{5}{*}{7 June 2002} & 0 & 18.3 & 5.4 & - & 20.4 & - & - & 6.6 & 49.3 \\
\hline & 50 & 20.1 & 3.8 & - & 24.7 & - & - & 5.5 & 45.9 \\
\hline & 100 & 19.1 & 4.4 & - & 21.7 & - & - & 7.9 & 46.8 \\
\hline & 150 & 16.7 & 2.8 & - & 27.0 & - & - & 5.6 & 47.8 \\
\hline & Significance & NS & NS & & NS & & & NS & NS \\
\hline \multirow{5}{*}{24 July 2002} & 0 & 24.3 & 8.3 & - & 19.1 & - & - & 7.6 & 40.7 \\
\hline & 50 & 31.3 & 10.5 & - & 10.2 & - & - & 3.1 & 45.0 \\
\hline & 100 & 23.7 & 7.7 & - & 15.7 & - & - & 5.6 & 47.3 \\
\hline & 150 & 17.0 & 7.1 & - & 20.5 & - & - & 8.2 & 47.1 \\
\hline & Significance & NS & NS & & $\mathrm{Q}^{* *}$ & & & $\mathrm{Q}^{* *} \mathrm{C}^{*}$ & NS \\
\hline \multirow[t]{5}{*}{29 Oct. 2002} & 0 & 15.3 & 14.1 & - & 14.4 & - & - & 10.6 & 45.6 \\
\hline & 50 & 24.9 & 17.4 & - & 10.3 & - & - & 9.5 & 37.9 \\
\hline & 100 & 28.8 & 15.9 & - & 13.0 & - & - & 9.8 & 32.5 \\
\hline & 150 & 22.4 & 11.3 & - & 20.0 & - & - & 7.1 & 39.3 \\
\hline & Significance & $\mathrm{L}^{*} \mathrm{Q}^{* *}$ & NS & & NS & & & $\mathrm{L}^{* *}$ & NS \\
\hline \multirow[t]{5}{*}{7 Feb. 2003} & 0 & - & - & - & 13.1 & 21.9 & - & 13.8 & 51.2 \\
\hline & 50 & - & - & - & 18.9 & 14.9 & - & 11.7 & 54.5 \\
\hline & 100 & - & - & - & 21.1 & 13.8 & - & 11.2 & 53.9 \\
\hline & 150 & - & - & - & 12.0 & 30.4 & - & 13.9 & 43.7 \\
\hline & Significance & & & & NS & NS & & NS & NS \\
\hline \multirow[t]{4}{*}{22 Apr. $2003^{x}$} & 0 & - & 2.0 & 2.5 & 13.2 & 11.9 & - & 21.6 & 48.9 \\
\hline & 50 & - & 4.2 & 2.1 & 14.6 & 13.0 & - & 15.9 & 50.2 \\
\hline & 100 & - & 3.3 & 2.0 & 11.7 & 16.8 & - & 16.7 & 49.5 \\
\hline & Significance & & NS & NS & NS & NS & & NS & NS \\
\hline \multirow[t]{4}{*}{22 May 2003} & 0 & 6.1 & 1.2 & 6.1 & 14.8 & 13.7 & - & 11.6 & 46.7 \\
\hline & 50 & 14.5 & 2.6 & 4.0 & 15.4 & 9.3 & - & 7.1 & 47.1 \\
\hline & 100 & 13.4 & 2.4 & 3.4 & 21.4 & 9.5 & - & 9.0 & 40.9 \\
\hline & Significance & $\mathrm{L}^{* *} \mathrm{Q}^{*}$ & $\mathrm{~L}^{*}$ & NS & NS & NS & & $\mathrm{Q}^{*}$ & NS \\
\hline \multirow[t]{4}{*}{27 July 2003} & 0 & 10.6 & 4.5 & 29.8 & 10.9 & 7.5 & - & 10.7 & 26.0 \\
\hline & 50 & 17.6 & 5.2 & 24.5 & 9.3 & 8.3 & - & 7.4 & 27.8 \\
\hline & 100 & 26.1 & 6.8 & 12.7 & 8.7 & 8.5 & - & 11.0 & 26.1 \\
\hline & Significance & NS & NS & NS & NS & NS & & NS & NS \\
\hline \multirow[t]{4}{*}{27 Oct. 2003} & 0 & 16.3 & 11.4 & - & 12.2 & 13.5 & - & 19.9 & 26.6 \\
\hline & 50 & 28.9 & 20.2 & - & 12.1 & 7.1 & - & 12.3 & 19.4 \\
\hline & 100 & 29.9 & 19.9 & - & 9.7 & 6.1 & - & 12.5 & 21.9 \\
\hline & Significance & $\mathrm{L}^{*}$ & $\mathrm{~L}^{* *} \mathrm{Q}^{*}$ & & NS & $\mathrm{L}^{* *}$ & & $\mathrm{~L}^{* *} \mathrm{Q}^{*}$ & NS \\
\hline \multirow[t]{4}{*}{21 Jan. 2004} & 0 & - & - & - & 13.2 & 14.4 & 17.6 & 13.8 & 41.0 \\
\hline & 50 & - & - & - & 16.8 & 14.2 & 16.8 & 11.5 & 40.7 \\
\hline & 100 & - & - & - & 23.1 & 12.7 & 13.8 & 11.7 & 38.8 \\
\hline & Significance & & & & NS & NS & NS & NS & NS \\
\hline
\end{tabular}

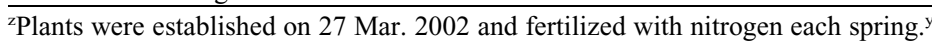

${ }^{y}$ Plants were leaf unfertilized after planting $(0)$ or were fertilized with 50,100 , or $150 \mathrm{~kg} \cdot \mathrm{ha}^{-1}$ of N in spring of each year.

${ }^{x}$ Most plants fertilized with $150 \mathrm{~kg} \cdot \mathrm{ha}^{-1}$ of $\mathrm{N}$ died by $22 \mathrm{Apr} .2003$.

${ }^{\mathrm{N}} \mathrm{NS}=$ nonsignificant; $\mathrm{L}=$ linear; $\mathrm{Q}=$ quadratic; or $\mathrm{C}=$ cubic response at $* P<0.05$ or $* * 0.01$ based on orthogonal contrasts.

$\mathrm{N}=$ nitrogen .
In $0 \mathrm{~N}$ plants, net biomass accumulation from planting to the beginning of the second growing season (after pruning in Feb. 2003) was $474 \mathrm{~kg} \cdot \mathrm{ha}^{-1}$ with losses of $119 \mathrm{~kg} \cdot \mathrm{ha}^{-1}$ in In plants fertilized with $50 \mathrm{~N}$, net biomass accumulation was $430 \mathrm{~kg} \cdot \mathrm{ha}^{-1}$ with losses of 255 and $254 \mathrm{~kg} \cdot \mathrm{ha}^{-1}$ in senescing leaves and prunings, respectively. Plants fertilized with piomass to 2002. The scenario was very similar the next season when $0 \mathrm{~N}$ plants accumulated 512 $\mathrm{kg} \cdot \mathrm{ha}^{-1}$ DW from Feb. 2003 to Jan. 2004 and lost only 323,158 , and $281 \mathrm{~kg} \cdot \mathrm{ha}^{-1}$ in 
fruit, senescing leaves, and prunings, respectively, whereas $50 \mathrm{~N}$ plants accumulated 611 $\mathrm{kg} \cdot \mathrm{ha}^{-1}$ DW and lost 475, 389, and 483 $\mathrm{kg} \cdot \mathrm{ha}^{-1}$, respectively. Clearly, $0 \mathrm{~N}$ plants allocated similar amounts of biomass to new canes, crown, and roots but much less biomass to leaves and fruit, as did $50 \mathrm{~N}$ or $100 \mathrm{~N}$ plants.

Allocation of DW varied with sample date and $\mathrm{N}$ rate (Table 1). Increasing rate of $\mathrm{N}$ fertilizer application increased DW allocation to leaves in the fall of 2002 and to leaves and new shoots in the spring and fall of 2003 but had no impact on allocation to flowers and fruit. Retamales and Hanson (1989) reported fruit DW accounted for $3.7 \%$ of total DW in fall on mature plants. In our study, on these young plants, fruit would have accounted for $17 \%, 33 \%$, and $35 \%$ of total plant DW in Oct. 2003 for the $100 \mathrm{~N}, 50 \mathrm{~N}$, and $0 \mathrm{~N}$ treatments, respectively, if fruit were included at this stage of development. Dry weight allocation to wood also responded significantly to $\mathrm{N}$ fertilization rate, but only in 1-year wood in July of 2002, when DW allocation to wood was lowest in $50 \mathrm{~N}$ plants, and in 2-year wood in Oct. 2003, when less DW was allocated to the wood as more $\mathrm{N}$ fertilizer was applied (Table 1). Belowground, plants often allocated less DW to crown tissue at higher $\mathrm{N}$ application rates, but there was little difference in the proportion of DW allocated to roots. Roots accounted for $35 \%$ of total plant DW at planting and, with the exception of plants fertilized with $150 \mathrm{~N}$, maximum allocation of DW to roots, $53 \%$ on average, occurred in Feb. 2003. Crown and root tissue accounted for $51 \%$ to $55 \%$ of total plant DW at the end of this study, similar to the $50 \%$ reported by others for mature blueberry plants (Pritts and Hancock, 1985; Retamales and Hanson, 1989).

Nitrogen uptake and partitioning. Total plant $\mathrm{N}$ content, which averaged $0.34 \mathrm{~g}$ at planting, was significantly affected by $\mathrm{N}$ rate over time $(P<0.0001)$ (Fig. 1B). Plants fertilized with $50 \mathrm{~N}$ accumulated more $\mathrm{N}$ by Oct. 2002 than $0 \mathrm{~N}$ or $150 \mathrm{~N}$ plants and more $\mathrm{N}$ than all treatments by fruit harvest in 2003. Plants fertilized with $50 \mathrm{~N}$ accumulated more than threefold the total $\mathrm{N}$ as $0 \mathrm{~N}$ plants in Oct. 2002, but by Feb. 2003, the total N content of $50 \mathrm{~N}$ plants was only $40 \%$ greater than that of $0 \mathrm{~N}$ plants as a result of greater losses of $\mathrm{N}$ over the winter of 2002-2003. By the end of the study in Jan. 2004, plants fertilized with $50 \mathrm{~N}$ gained a total of $17.8 \mathrm{~kg} \cdot \mathrm{ha}^{-1}$ of $\mathrm{N}$ and lost $6.5 \mathrm{~kg} \cdot \mathrm{ha}^{-1}$ of $\mathrm{N}$ in fruit and $13.3 \mathrm{~kg} \cdot \mathrm{ha}^{-1}$ of $\mathrm{N}$ in senescing leaves, whereas $100 \mathrm{~N}$ plants gained only $9.2 \mathrm{~kg} \cdot \mathrm{ha}^{-1}$ of $\mathrm{N}$ and lost $2.5 \mathrm{~kg} \cdot \mathrm{ha}^{-1}$ of $\mathrm{N}$ in fruit and $9.7 \mathrm{~kg} \cdot \mathrm{ha}^{-1}$ of $\mathrm{N}$ in senescing leaves. The $0 \mathrm{~N}$ plants gained 9.9 $\mathrm{kg} \cdot \mathrm{ha}^{-1}$ of $\mathrm{N}$, similar to $100 \mathrm{~N}$ plants, but lost $3.6 \mathrm{~kg} \cdot \mathrm{ha}^{-1}$ of $\mathrm{N}$ in fruit and $2.3 \mathrm{~kg} \cdot \mathrm{ha}^{-1}$ of $\mathrm{N}$ in senescing leaves, much less than that found in the $50 \mathrm{~N}$ and $100 \mathrm{~N}$ plants. Nitrogen was also lost by removal of wood when pruning each winter; the $0 \mathrm{~N}$ plants lost a total of 2.2 $\mathrm{kg} \cdot \mathrm{ha}^{-1}$ of $\mathrm{N}$, whereas $50 \mathrm{~N}$ and $100 \mathrm{~N}$ plants lost 6.9 and $1.9 \mathrm{~kg} \cdot \mathrm{ha}^{-1}$ of $\mathrm{N}$, respectively. Note that any $\mathrm{N}$ in abscised leaves and prunings that are chopped and left in the field (as is common commercial practice) would likely return to the plant/soil system as materials decompose. Nitrogen recovery from leaves and flailed prunings averaged $9 \%$ over 2 years in kiwifruit (Actinidia deliciosa A. Cher.; Ledgard et al., 1992) and 8\% over 1.5 years in red raspberry (Rubus idaeus L.; Strik et al., 2006).

Nitrogen fertilization rate also affected allocation of total $\mathrm{N}$ within plants (Table 2). Increasing rate of $\mathrm{N}$ fertilizer application increased allocation of $\mathrm{N}$ to leaves from July to leaf senescence in October, but allocation of $\mathrm{N}$ to the crown and roots declined with increasing $\mathrm{N}$ rate on many dates. Plants also generally allocated more $\mathrm{N}$ to woody canes with higher $\mathrm{N}$ rate, although results varied with wood age and sample date. The proportion of total plant $\mathrm{N}$ present in the leaves in fall in the young fertilized plants $(41 \%$ to $48 \%$ in 2002 and $20 \%$ to $36 \%$ in 2003 ) was higher than that reported for mature plants (17\%; Retamales and Hanson, 1989), suggesting that relative allocation of total $\mathrm{N}$ to leaves may decrease in older plantings. In Jan. 2004, allocation of $\mathrm{N}$ among canes, crown, and roots was similar between fertilized $(50 \mathrm{~N}$ and $100 \mathrm{~N}$ ) and $0 \mathrm{~N}$ plants (Table 2).

With few exceptions, $\mathrm{N}$ concentration in each plant part was lowest in $0 \mathrm{~N}$ plants and

Table 2. Nitrogen $(\mathrm{N})$ allocation among different parts of young 'Bluecrop' blueberries during the first 2 years after planting. ${ }^{\mathrm{z}}$

\begin{tabular}{|c|c|c|c|c|c|c|c|c|c|}
\hline \multirow[b]{3}{*}{ Sample date } & \multicolumn{9}{|c|}{$\mathrm{N}$ allocation (\%) } \\
\hline & \multirow[b]{2}{*}{$\begin{array}{l}\text { N fertilizer } \\
\left(\mathrm{kg} \cdot \mathrm{ha}^{-1}\right)\end{array}$} & \multirow[b]{2}{*}{ Leaves } & \multirow[b]{2}{*}{$\begin{array}{l}\text { New } \\
\text { shoots }\end{array}$} & \multirow[b]{2}{*}{ Flowers/fruit } & \multicolumn{3}{|c|}{ Woody canes } & \multirow[b]{2}{*}{ Crown } & \multirow[b]{2}{*}{ Roots } \\
\hline & & & & & $\begin{array}{c}1 \text { year } \\
\text { old }\end{array}$ & $\begin{array}{l}2 \text { years } \\
\text { old }\end{array}$ & $\begin{array}{c}3 \text { years } \\
\text { old }\end{array}$ & & \\
\hline 27 Mar. 2002 & - & - & - & - & 59.2 & - & - & - & 40.8 \\
\hline \multirow[t]{5}{*}{29 Apr. 2002} & 0 & - & 20.3 & - & 39.9 & - & - & 9.7 & 30.1 \\
\hline & 50 & - & 22.4 & - & 33.4 & - & - & 7.6 & 36.6 \\
\hline & 100 & - & 27.5 & - & 37.0 & - & - & 11.5 & 23.9 \\
\hline & 150 & - & 13.9 & - & 32.5 & - & - & 7.4 & 46.2 \\
\hline & Significance $^{\mathrm{w}}$ & & NS & & NS & & & NS & NS \\
\hline \multirow[t]{5}{*}{7 June 2002} & 0 & 33.0 & 5.2 & - & 10.3 & - & - & 6.7 & 44.8 \\
\hline & 50 & 32.5 & 3.1 & - & 16.6 & - & - & 5.5 & 42.3 \\
\hline & 100 & 34.2 & 3.8 & - & 14.5 & - & - & 7.4 & 40.1 \\
\hline & 150 & 24.2 & 2.5 & - & 20.5 & - & - & 5.5 & 47.4 \\
\hline & Significance & NS & NS & & $\mathrm{L}^{* *} \mathrm{C}^{*}$ & & & NS & NS \\
\hline \multirow[t]{5}{*}{24 July 2002} & 0 & 31.5 & 5.1 & - & 6.6 & - & - & 3.4 & 53.5 \\
\hline & 50 & 50.6 & 8.3 & - & 7.1 & - & - & 2.2 & 31.8 \\
\hline & 100 & 40.5 & 7.6 & - & 12.8 & - & - & 5.7 & 33.4 \\
\hline & 150 & 35.3 & 7.4 & - & 16.5 & - & - & 8.1 & 32.8 \\
\hline & Significance & NS & NS & & $\mathrm{L}^{* *}$ & & & $\mathrm{~L}^{* *}$ & $\mathrm{~L}^{*} \mathrm{Q} *$ \\
\hline \multirow[t]{5}{*}{29 Oct. 2002} & 0 & 13.9 & 15.6 & - & 12.4 & - & - & 11.2 & 46.8 \\
\hline & 50 & 40.7 & 14.0 & - & 8.6 & - & - & 8.1 & 28.7 \\
\hline & 100 & 47.7 & 12.7 & - & 9.9 & - & - & 7.5 & 22.2 \\
\hline & 150 & 42.0 & 11.3 & - & 17.1 & - & - & 7.3 & 22.3 \\
\hline & Significance & $\mathrm{L}^{* *} \mathrm{Q} * *$ & $\mathrm{~L}^{* *}$ & & $\mathrm{Q}^{*}$ & & & $\mathrm{~L}^{* *}$ & $\mathrm{~L}^{* *} \mathrm{Q} *$ \\
\hline \multirow[t]{5}{*}{7 Feb. 2003} & 0 & - & - & - & 10.1 & 12.5 & - & 15.5 & 61.9 \\
\hline & 50 & - & - & - & 22.0 & 16.1 & - & 14.3 & 47.6 \\
\hline & 100 & - & - & - & 27.6 & 15.4 & - & 12.3 & 44.7 \\
\hline & 150 & - & - & - & 20.2 & 34.3 & - & 13.9 & 31.6 \\
\hline & Significance & & & & NS & NS & & NS & $\mathrm{L}^{* *}$ \\
\hline \multirow[t]{4}{*}{22 Apr. $2003^{x}$} & 0 & - & 9.0 & 10.5 & 8.6 & 5.9 & - & 21.6 & 44.3 \\
\hline & 50 & - & 14.4 & 7.5 & 13.9 & 11.9 & - & 17.2 & 35.2 \\
\hline & 100 & - & 10.4 & 7.0 & 11.4 & 14.3 & - & 18.8 & 38.1 \\
\hline & Significance & & NS & NS & NS & $\mathrm{L}^{* *}$ & & NS & NS \\
\hline \multirow{4}{*}{22 May 2003} & 0 & 18.5 & 1.8 & 17.1 & 9.2 & 5.2 & - & 8.1 & 40.2 \\
\hline & 50 & 30.0 & 2.7 & 8.7 & 10.9 & 5.6 & - & 4.8 & 37.3 \\
\hline & 100 & 26.7 & 2.8 & 7.3 & 16.9 & 6.3 & - & 7.3 & 32.7 \\
\hline & Significance & $\mathrm{L}^{*} \mathrm{Q} *$ & $\mathrm{~L}^{*}$ & $\mathrm{~L}^{*}$ & NS & NS & & NS & NS \\
\hline \multirow[t]{4}{*}{27 July 2003} & 0 & 18.6 & 3.3 & 35.3 & 5.8 & 4.5 & - & 7.5 & 24.8 \\
\hline & 50 & 26.9 & 3.7 & 23.7 & 5.1 & 4.5 & - & 5.7 & 30.5 \\
\hline & 100 & 35.8 & 4.8 & 12.6 & 4.5 & 3.9 & - & 9.1 & 29.3 \\
\hline & Significance & NS & NS & NS & NS & NS & & NS & NS \\
\hline \multirow[t]{4}{*}{27 Oct. 2003} & 0 & 19.7 & 13.2 & - & 9.0 & 8.3 & - & 18.4 & 31.3 \\
\hline & 50 & 35.9 & 14.3 & - & 8.7 & 4.9 & - & 10.8 & 25.4 \\
\hline & 100 & 20.3 & 28.1 & - & 7.4 & 4.1 & - & 10.5 & 29.5 \\
\hline & Significance & $\mathrm{Q}^{* *}$ & $\mathrm{~L}^{*}$ & & NS & NS & & NS & NS \\
\hline \multirow[t]{4}{*}{21 Jan. 2004} & 0 & - & - & - & 12.2 & 10.4 & 10.4 & 12.4 & 54.5 \\
\hline & 50 & - & - & - & 15.9 & 11.5 & 10.0 & 9.5 & 53.0 \\
\hline & 100 & - & - & - & 21.0 & 10.1 & 8.7 & 9.5 & 50.6 \\
\hline & Significance & & & & NS & NS & NS & NS & NS \\
\hline
\end{tabular}

"Plants were established on 27 Mar. 2002 and fertilized with $\mathrm{N}$ each spring. ${ }^{\mathrm{y}}$

yPlants were leaf unfertilized after planting $(0)$ or were fertilized with 50,100 , or $150 \mathrm{~kg} \cdot \mathrm{ha}^{-1}$ of $\mathrm{N}$ in spring of each year.

${ }^{\mathrm{x}}$ Most plants fertilized with $150 \mathrm{~kg} \cdot \mathrm{ha}^{-1}$ of $\mathrm{N}$ died by $22 \mathrm{Apr} .2003$.

$\mathrm{w}_{\mathrm{NS}}=$ nonsignificant; $\mathrm{L}=$ linear; $\mathrm{Q}=$ quadratic; or $\mathrm{C}=$ cubic response at $* P<0.05$ or $* * 0.01$ based on orthogonal contrasts. 
often increased significantly as more $\mathrm{N}$ fertilizer was applied (Table 3). Based on nutrient guidelines for blueberry (Hart et al., 2006), leaf $\mathrm{N}$ concentration in late July was deficient (less than 1.5\%) each year in $0 \mathrm{~N}$ plants and above normal (greater than $2.0 \%$ ) in all fertilized plants (Table 3 ). Leaf $\mathrm{N}$ concentrations in this study were from a subsample of all leaf tissue on each sample date and therefore may have underestimated the $\mathrm{N}$ concentration in the most recent fully expanded leaves on which nutrient standards are based. It is possible that current leaf $\mathrm{N}$ standards, generally used for producing plants, may need to be increased for young plants.

Leaf $\mathrm{N}$ concentration declined from early spring through fall, as found by others (Bailey et al., 1962; Cheng and Raba, 2009; Ledgard and Smith, 1992; Retamales and Hanson, $1990)$ with the exception of $150 \mathrm{~N}$ plants, which had high leaf $\mathrm{N}$ concentration and symptoms of salt stress and poor growth (Table 3). Flower and fruit $\mathrm{N}$ concentration also declined from flowering to fruit harvest but was higher than the fruit $\mathrm{N}$ concentrations observed by Ballinger and Kushman (1966) and Bishop et al. (1971). The presence of immature and mature fruit on the July sample date likely overestimated fruit $\mathrm{N}$ concentration. Like with mature plants (Retamales and Hanson, 1989), wood N concentration was inversely related to wood age with highest concentrations in new shoots and lowest in 3year-old canes. Belowground, crown N concentration decreased each summer but only in $0 \mathrm{~N}$ and $50 \mathrm{~N}$ plants. Root $\mathrm{N}$ concentration, on the other hand, peaked in June or July the first year after planting and increased throughout the season the next year regardless of the amount of $\mathrm{N}$ applied.

Nitrogen fertilizer recovery. Plant NDFF was affected by $\mathrm{N}$ rate $(P<0.01)$ and by sampling date $(P<0.0001)$ (Fig. $1 C)$. The $50 \mathrm{~N}$ and $100 \mathrm{~N}$ plants had more NDFF than the $150 \mathrm{~N}$ plants. Fertilizer $\mathrm{N}$ was found in every plant part and allocation varied throughout the year (Fig. 2).

By Oct. 2002, plants recovered 17\% (3.2 g) of the applied fertilizer when $50 \mathrm{~N}$ was applied, $10 \%(3.6 \mathrm{~g})$ when $100 \mathrm{~N}$ was applied, and only $3 \%$ (1.7 g) when $150 \mathrm{~N}$ was applied. These amounts accounted for $58 \%$ to $70 \%$ of the total $\mathrm{N}$ in the plants, depending on $\mathrm{N}$ rate. In the $50 \mathrm{~N}$ plants, $\approx 79 \%$ was allocated aboveground to leaves, new shoots, and woody canes (Figs. 2A, C, and D); thus, like total DW and $\mathrm{N}$ content, fertilizer $\mathrm{N}$ declined sharply over winter as a result of leaf abscission and pruning. After pruning, in Feb. 2003, an average of $60 \%$ of the total $\mathrm{N}$ in fertilized plants was NDFF, considerably higher than the $6 \%$ found in mature plants by Retamales and Hanson (1989).

In the $50 \mathrm{~N}$ plants, $40 \%$ of the NDFF remaining after pruning in 2002-2003 was in woody canes, $46 \%$ in the roots, and $14 \%$ was in the crown (Fig. 2D-F). This stored N was likely an important source of $\mathrm{N}$ for new plant growth, as documented in potted rabbiteye blueberry ( $V$. virgatum Ait.) plants (Birkhold and Darnell, 1993). We could not directly measure plant use of stored NDFF in the second year, because the content of labeled $\mathrm{N}$ in fertilized plants increased from Apr. to July 2003 (Fig. 1C); this likely reflected uptake of fertilizer $\mathrm{N}$, applied the previous year, from soil and possibly recycled fertilizer $\mathrm{N}$ from abscised, decomposed leaves and turnover of fine roots. Fine roots contain high concentrations of $\mathrm{N}$ and turnover readily under unfavorable soil conditions in blueberry (Valenzuela-Estrada et al., 2008). However, at the beginning of this period in Apr. 2003, 63\% of the total $\mathrm{N}$ in flowers and new shoots of $50 \mathrm{~N}$ plants was likely from stored NDFF, because presumably little to no $\mathrm{N}$ uptake had yet occurred that early in the season (Fig. 2B-C).

Total N and NDFF stored in the roots, crown, and woody canes of $50 \mathrm{~N}$ plants declined in Spring 2003 as total N and NDFF in new growth increased (Fig. 2A-F).

In 2003 , most new uptake of ${ }^{15} \mathrm{~N}$ from fertilizer applied in 2002 occurred in the roots (Fig. 2F). In July 2003, 25\% of total fruit $\mathrm{N}$ at harvest, in plants fertilized with $50 \mathrm{~N}$, was NDFF applied in 2002; any remaining $\mathrm{N}$ would have come from soil sources, stored $\mathrm{N}$ in the original planting material, or unlabeled fertilizer applied the second year (Fig. 2B). In mature kiwifruit, results were similar with $\approx 60 \%$ of the $\mathrm{N}$ used for new growth and production being from remobilization of $\mathrm{N}$ stored within the vines and $\approx 40 \%$

Table 3. Nitrogen $(\mathrm{N})$ concentration in different parts of young 'Bluecrop' blueberries during the first 2 years after planting. ${ }^{\mathrm{z}}$

\begin{tabular}{|c|c|c|c|c|c|c|c|c|c|}
\hline \multirow[b]{3}{*}{ Sample date } & \multicolumn{9}{|c|}{$\mathrm{N}$ conch $(\%)$} \\
\hline & \multirow[b]{2}{*}{$\begin{array}{l}\mathrm{N} \text { fertilizer } \\
\left(\mathrm{kg} \cdot \mathrm{ha}^{-1}\right)\end{array}$} & \multirow[b]{2}{*}{ Leaves } & \multirow[b]{2}{*}{$\begin{array}{l}\text { New } \\
\text { shoots }\end{array}$} & \multirow[b]{2}{*}{ Flowers/fruit } & \multicolumn{3}{|c|}{ Woody canes } & \multirow[b]{2}{*}{ Crown } & \multirow[b]{2}{*}{ Roots } \\
\hline & & & & & $\begin{array}{l}1 \text { year } \\
\text { old }\end{array}$ & $\begin{array}{c}2 \text { years } \\
\text { old }\end{array}$ & $\begin{array}{c}3 \text { years } \\
\text { old }\end{array}$ & & \\
\hline 27 Mar. 2002 & - & - & - & - & 1.16 & - & - & - & 1.58 \\
\hline \multirow[t]{5}{*}{29 Apr. 2002} & 0 & - & 3.08 & - & 1.08 & - & - & 1.49 & 0.95 \\
\hline & 50 & - & 3.36 & - & 1.12 & - & - & 1.30 & 1.07 \\
\hline & 100 & - & 3.41 & - & 1.02 & - & - & 1.35 & 1.32 \\
\hline & 150 & - & 3.12 & - & 1.19 & - & - & 1.28 & 1.68 \\
\hline & Significance ${ }^{\mathrm{w}}$ & & NS & & NS & & & NS & NS \\
\hline \multirow[t]{5}{*}{7 June 2002} & 0 & 1.92 & 1.00 & - & 0.54 & - & - & 1.10 & 0.96 \\
\hline & 50 & 2.70 & 1.27 & - & 1.13 & - & - & 1.68 & 1.56 \\
\hline & 100 & 2.87 & 1.40 & - & 1.07 & - & - & 1.52 & 1.38 \\
\hline & 150 & 2.76 & 1.65 & - & 1.41 & - & - & 1.87 & 1.85 \\
\hline & Significance & $\mathrm{L}^{*}$ & $\mathrm{~L}^{* *}$ & & $\mathrm{~L}^{* *} \mathrm{C}^{*}$ & & & $\mathrm{~L}^{*}$ & $\mathrm{~L}^{* *} \mathrm{C}^{*}$ \\
\hline \multirow[t]{5}{*}{24 July 2002} & 0 & 1.42 & 0.66 & - & 0.37 & - & - & 0.48 & 1.44 \\
\hline & 50 & 2.82 & 1.32 & - & 1.19 & - & - & 1.21 & 1.25 \\
\hline & 100 & 2.81 & 1.59 & - & 1.33 & - & - & 1.65 & 1.11 \\
\hline & 150 & 3.84 & 1.79 & - & 1.38 & - & - & 1.69 & 1.19 \\
\hline & Significance & $\mathrm{L}^{* *}$ & $\mathrm{~L}^{* *}$ & & $\mathrm{~L}^{* *} \mathrm{Q} * *$ & & & $\mathrm{~L}^{* *}$ & NS \\
\hline \multirow[t]{5}{*}{29 Oct. 2002} & 0 & 0.54 & 0.67 & - & 0.53 & - & - & 0.63 & 0.61 \\
\hline & 50 & 2.39 & 1.19 & - & 1.24 & - & - & 1.27 & 1.12 \\
\hline & 100 & 3.01 & 1.47 & - & 1.40 & - & - & 1.39 & 1.28 \\
\hline & 150 & 3.73 & 1.97 & - & 1.67 & - & - & 2.04 & 1.11 \\
\hline & Significance & $\mathrm{L}^{* *} \mathrm{Q}^{*}$ & $\mathrm{~L}^{* *}$ & & $\mathrm{~L}^{* *} \mathrm{Q}^{*}$ & & & $\mathrm{~L}^{* *}$ & $\mathrm{~L}^{*} \mathrm{Q}^{*}$ \\
\hline \multirow[t]{5}{*}{7 Feb. 2003} & 0 & - & - & - & 0.78 & 0.56 & - & 1.07 & 1.18 \\
\hline & 50 & - & - & - & 1.70 & 1.58 & - & 1.73 & 1.34 \\
\hline & 100 & - & - & - & 2.07 & 1.77 & - & 1.72 & 1.32 \\
\hline & 150 & - & - & - & 2.91 & 1.87 & - & 1.52 & 1.22 \\
\hline & Significance & & & & $\mathrm{L}^{* *}$ & $\mathrm{~L}^{* *} \mathrm{Q} * *$ & & NS & NS \\
\hline \multirow[t]{4}{*}{22 Apr. $2003^{x}$} & 0 & - & 3.51 & 3.26 & 0.51 & 0.38 & - & 0.76 & 0.70 \\
\hline & 50 & - & 4.67 & 5.28 & 1.32 & 1.26 & - & 1.48 & 0.95 \\
\hline & 100 & - & 4.74 & 5.05 & 1.40 & 1.23 & - & 1.59 & 1.11 \\
\hline & Significance & & $\mathrm{L}^{* *} \mathrm{Q}^{*}$ & $\mathrm{~L}^{*} \mathrm{Q}^{*}$ & $\mathrm{~L}^{* *} \mathrm{Q}^{*}$ & $\mathrm{~L}^{* *} \mathrm{Q} * *$ & & $\mathrm{~L}^{* *}$ & $\mathrm{~L}^{* *}$ \\
\hline \multirow{4}{*}{22 May 2003} & 0 & 2.77 & 1.43 & 2.52 & 0.56 & 0.35 & - & 0.64 & 0.77 \\
\hline & 50 & 2.95 & 1.53 & 3.09 & 0.98 & 0.84 & - & 0.95 & 1.12 \\
\hline & 100 & 3.34 & 2.02 & 3.53 & 1.30 & 1.09 & - & 1.34 & 1.34 \\
\hline & Significance & $\mathrm{L}^{*}$ & $\mathrm{~L}^{* *}$ & $\mathrm{~L}^{* *}$ & $\mathrm{~L}^{* *}$ & $\mathrm{~L}^{* *}$ & & $\mathrm{~L}^{* *}$ & $\mathrm{~L}^{* *}$ \\
\hline \multirow[t]{4}{*}{27 July 2003} & 0 & 1.42 & 0.66 & 1.05 & 0.48 & 0.52 & - & 0.66 & 0.88 \\
\hline & 50 & 2.23 & 1.05 & 1.37 & 0.81 & 0.76 & - & 1.14 & 1.60 \\
\hline & 100 & 2.26 & 1.34 & 1.79 & 1.00 & 0.86 & - & 1.57 & 2.15 \\
\hline & Significance & NS & $\mathrm{L}^{* *}$ & $\mathrm{~L}^{*}$ & $\mathrm{~L}^{*}$ & NS & & $\mathrm{L}^{*}$ & $\mathrm{~L}^{* *}$ \\
\hline \multirow[t]{4}{*}{27 Oct. 2003} & 0 & 1.10 & 1.07 & - & 0.68 & 0.56 & - & 0.84 & 1.08 \\
\hline & 50 & 1.85 & 1.06 & - & 1.05 & 1.05 & - & 1.32 & 1.94 \\
\hline & 100 & 1.11 & 2.34 & - & 1.29 & 1.10 & - & 1.37 & 2.18 \\
\hline & Significance & $\mathrm{Q}^{* *}$ & $\mathrm{~L}^{* *} \mathrm{Q}^{*}$ & & $\mathrm{~L}^{*}$ & NS & & NS & $\mathrm{L}^{* *} \mathrm{Q}^{*}$ \\
\hline \multirow[t]{4}{*}{21 Jan. 2004} & 0 & - & - & - & 0.96 & 0.74 & 0.61 & 0.92 & 1.37 \\
\hline & 50 & - & - & - & 1.61 & 1.41 & 1.03 & 1.43 & 2.30 \\
\hline & 100 & - & - & - & 1.56 & 1.35 & 1.13 & 1.44 & 2.28 \\
\hline & Significance & & & & $\mathrm{L}^{*}$ & $\mathrm{~L}^{* *} \mathrm{Q} *$ & $\mathrm{~L}^{* *}$ & $\mathrm{~L}^{*}$ & $\mathrm{~L}^{* *} \mathrm{Q}^{* *}$ \\
\hline
\end{tabular}

${ }^{2}$ Plants were established on 27 Mar. 2002 and fertilized with nitrogen each spring. ${ }^{\mathrm{y}}$

y Plants were leaf unfertilized after planting $(0)$ or were fertilized with 50,100 , or $150 \mathrm{~kg} \cdot \mathrm{ha}^{-1}$ of N in spring of each year.

${ }^{x}$ Most plants fertilized with $150 \mathrm{~kg} \cdot \mathrm{ha}^{-1}$ of N died by $22 \mathrm{Apr} .2003$.

${ }^{\mathrm{w}_{\mathrm{NS}}}=$ nonsignificant; $\mathrm{L}=$ linear; $\mathrm{Q}=$ quadratic; or $\mathrm{C}=$ cubic response at $* P<0.05$ or $* * 0.01$ based on orthogonal contrasts. 

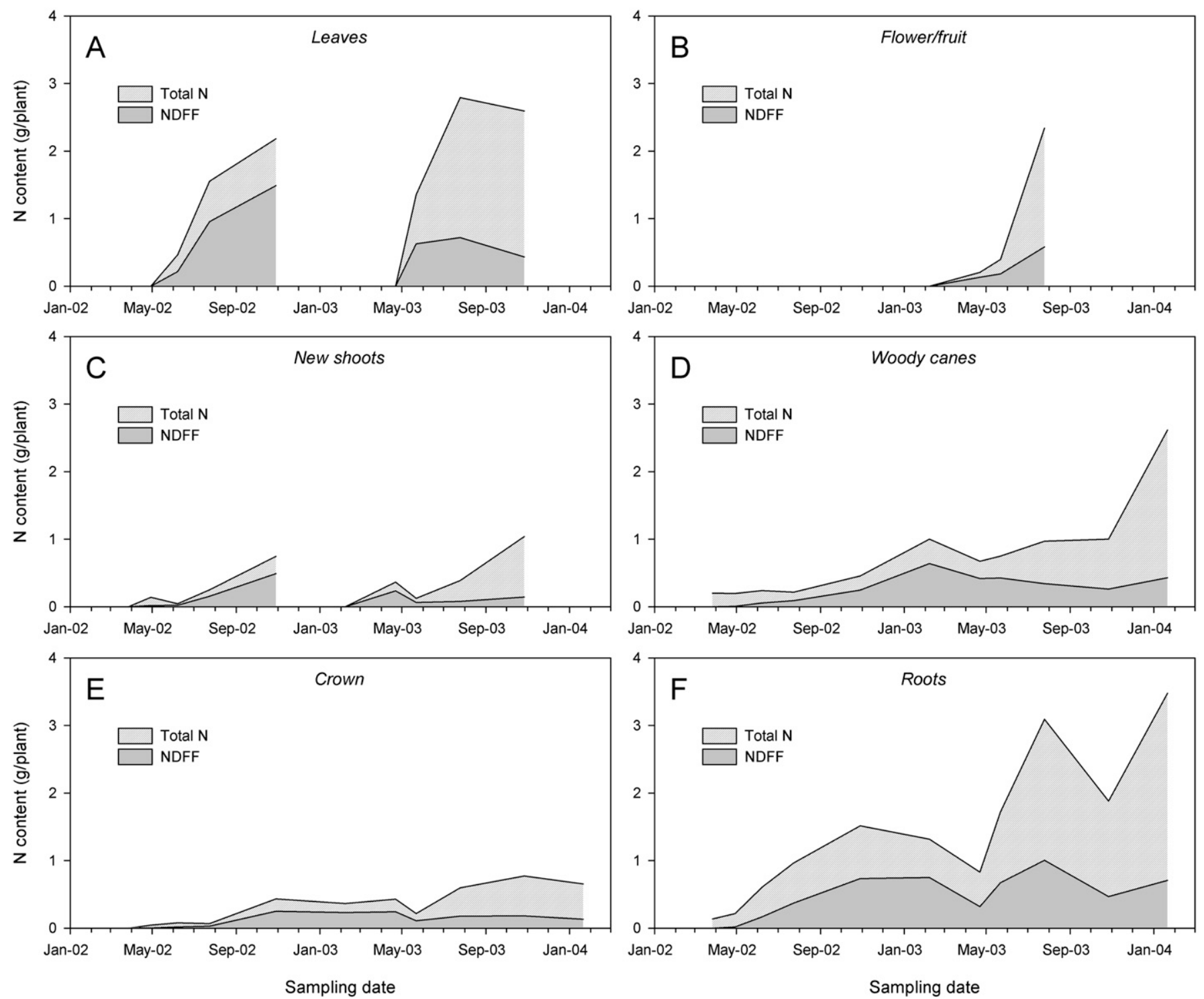

Fig. 2. Total nitrogen $(\mathrm{N})$ and $\mathrm{N}$ derived from fertilizer (NDFF) in leaves $(\mathbf{A})$, flowers and fruit $(\mathbf{B})$, new shoots $(\mathbf{C})$, woody canes $(\mathbf{D})$, crown $(\mathbf{E})$, and roots $(\mathbf{F})$ of young plants of 'Bluecrop' blueberry. Plants were established in the field on $27 \mathrm{Mar}$. 2002 and fertilized each spring with $50 \mathrm{~kg} \cdot \mathrm{ha}{ }^{-1}$ of N. NDFF represents labeled $\mathrm{N}$ applied during the first year after planting and does not include any $\mathrm{N}$ applied the next year. Time of fertilizer application is provided in Figure 1. Each symbol represents the mean of three replicates and error bars represent \pm 1 SE.

from fertilizer and soil sources (Ledgard and Smith, 1992).

By the end of the second season in Oct. 2003, NDFF applied the first year accounted for $20 \%$ of the total $\mathrm{N}$ in plants fertilized with $50 \mathrm{~N}$ and $24 \%$ of the total $\mathrm{N}$ in plants fertilized with $100 \mathrm{~N}$. By the end of the study, in Jan. 2004, 0N plants had accumulated $3.6 \mathrm{~g}$ of $\mathrm{N}$ ( or $9.6 \mathrm{~kg} \cdot \mathrm{ha}^{-1}$ ). The $50 \mathrm{~N}$ plants accumulated $6.4 \mathrm{~g}$ of $\mathrm{N}$, but only $20 \%$ of the accumulated $\mathrm{N}(1.3 \mathrm{~g} /$ plant $)$ came from the fertilizer applied in 2002; the rest came from soil-available $\mathrm{N}$ or recycled $\mathrm{N}$ from abscised leaves or root turnover. Plants fertilized with $100 \mathrm{~N}$ had 33\% NDFF in Jan. 2004 but grew less and accumulated less $\mathrm{N}$ (3.3 g/plant) than those fertilized with $50 \mathrm{~N}$.

Soil $\mathrm{pH}$ and availability of soil nitrogen. Soil $\mathrm{pH}$, availability of inorganic soil $\mathrm{N}$, and soil NDFF all differed among $\mathrm{N}$ rates over time $(P<0.0001)$ (Fig. 3). Soil $\mathrm{pH}$ declined by $0.6-1.1$ units with $\mathrm{N}$ fertilizer but was similar regardless of the amount of $\mathrm{N}$ applied (Fig. 3A). Soil $\mathrm{pH}$ in $0 \mathrm{~N}$ plots remained between 4.7 and 5.4 in both years, whereas soil $\mathrm{pH}$ in fertilized plots declined from an average of 4.7 in Apr. 2002 to $\approx 4.0$ by the end of the year, a value considered somewhat low for highbush blueberry (Hart et al., 2006). In a 6-year study in Nova Scotia, Canada, yield was highest in unfertilized plants, likely because fertilization reduced soil $\mathrm{pH}$ below 4.0 (Thompson, 1973).

Soil $\mathrm{NH}_{4}{ }^{+}$and $\mathrm{NO}_{3}{ }^{-}$levels in the nursery plant potting mix, at planting, averaged 2.2 and $0.1 \mathrm{mg} \cdot \mathrm{kg}^{-1}$, respectively. Soil $\mathrm{NH}_{4}{ }^{+}$and $\mathrm{NO}_{3}{ }^{-}$levels increased as more $\mathrm{N}$ fertilizer was applied (Fig. 3B-C). In general, soil $\mathrm{NH}_{4}{ }^{+}$increased rapidly after each $\mathrm{N}$ fertilizer application and then declined gradually over the growing season, whereas soil $\mathrm{NO}_{3}^{-}$increased gradually until fall and then declined quickly over the winter rainy season. In $0 \mathrm{~N}$ plots, soil $\mathrm{NO}_{3}{ }^{-}$levels remained low, only increasing slightly in late spring/early summer the second year, as soil temperatures warmed up (Fig. 3C).

Even at the soil $\mathrm{pH}$ found in this study and with ammonium fertilizer applied, soil $\mathrm{NO}_{3}{ }^{-}$ levels were relatively high, especially for the high rates of $\mathrm{N}$ fertilizer, in late summer/fall (Fig. 3C). Nitrification rates have been shown to be high in blueberry soils despite the low pH typically found (Hanson et al., 2002; Retamales and Hanson, 1990). Soil $\mathrm{NO}_{3}{ }^{-}$ declined from fall to late winter in each year, because $\mathrm{NO}_{3}{ }^{-}$either moved beyond the soil sampling zone or was lost as a result of leaching. Soil $\mathrm{NO}_{3}{ }^{-}$also decreased over winter in Michigan (Retamales and Hanson, 1990).

Although we were not able to determine the total amount of fertilizer $\mathrm{N}$ remaining in the soil around the root zone of the blueberry plants, we did measure the proportion of the total N in the soil that was NDFF. Soil NDFF increased, as expected, with application of 

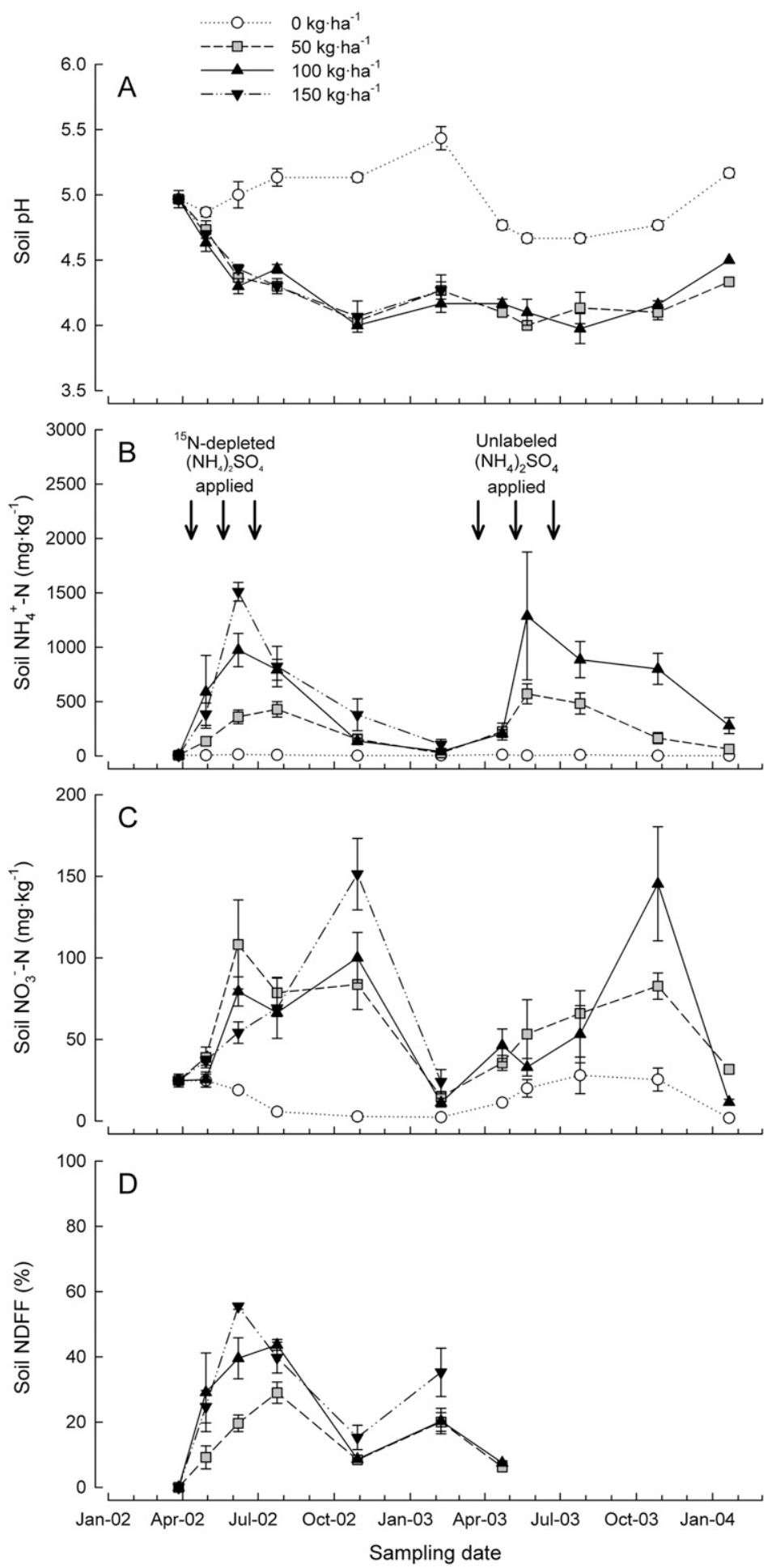

Fig. 3. Soil $\mathrm{pH}(\mathbf{A}), \mathrm{NH}_{4}{ }^{+}-\mathrm{N}(\mathbf{B}), \mathrm{NO}_{3}{ }^{-}-\mathrm{N}(\mathbf{C})$, and $\mathrm{N}$ derived from fertilizer (NDFF) (D) under young plants of 'Bluecrop' blueberry. Plants were established on 27 Mar. 2002 and left unfertilized after planting (0) or fertilized each spring with 50,100 , or $150 \mathrm{~kg} \cdot \mathrm{ha}^{-1}$ of $\mathrm{N}$. Each symbol represents the mean of three replicates and error bars represent \pm 1 SE. Arrows $(\mathbf{B})$ denote times of $\mathrm{N}$ fertilizer application. Soil $\mathrm{NH}_{4}{ }^{+}$ and $\mathrm{NO}_{3}^{-}$levels in the nursery plant potting mix, at planting, averaged 2.2 and $0.1 \mathrm{mg} \cdot \mathrm{kg}^{-1}$, respectively. NDFF data were not available for soil samples taken after May 2003.

${ }^{15} \mathrm{~N}$-depleted fertilizer, peaking after the third application at $29 \%$ of the total soil $\mathrm{N}$ when $50 \mathrm{~N}$ was applied and at $44 \%$ when $100 \mathrm{~N}$ was applied but then declined in late summer, likely as a result of plant uptake (Fig. 3D). Approximately $10 \%$ to $18 \%$ of the total $\mathrm{N}$ in the soil samples in October was NDFF, similar to the levels found in top soil under mature, fertilized blueberry plants at the end of the season in Michigan (Retamales and Hanson, 1989). Interestingly, over winter, from Oct. 2002 to Feb. 2003, soil NDFF level increased again, perhaps as a result of decomposition of leaf litter but also possibly from turnover of fine roots (Valenzuela-Estrada et al., 2008). This increase over winter was then followed by another decline in soil NDFF in early spring (Fig. 3B) as a result of root uptake (Figs. $1 \mathrm{C}$ and $2 \mathrm{~F}$ ), although additional $\mathrm{N}$ fertilizer (unlabeled) was applied.

\section{Conclusions}

Application of $50 \mathrm{~kg} \cdot \mathrm{ha}^{-1}$ of $\mathrm{N}$ produced more growth and fruit production during the first 2 years after planting than either 100 or $150 \mathrm{~kg} \cdot \mathrm{ha}^{-1}$ of $\mathrm{N}$ as well as no $\mathrm{N}$. This low rate of $\mathrm{N}$, applied by hand around the drip line of each plant, was the best $\mathrm{N}$ fertilizer treatment at this planting density (2777 plants/ha); higher rates may be required in the establishment year for greater planting densities, until the plant canopies fill the in-row area. By the end of the first growing season, plants recovered $17 \%$ of the fertilizer $\mathrm{N}$ applied at $50 \mathrm{~kg} \cdot \mathrm{ha}^{-1} \mathrm{~N}, 10 \%$ applied at $100 \mathrm{~kg} \cdot \mathrm{ha}^{-1} \mathrm{~N}$ and only $3 \%$ applied at $150 \mathrm{~kg} \cdot \mathrm{ha}^{-1} \mathrm{~N}$. Additional fertilizer $\mathrm{N}$ applied the first season was taken up the next year, and by the beginning of the third season, $20 \%$ to $24 \%$ still remained in the plant.

During the first year after planting, plants grown without additional $\mathrm{N}$ fertilizer derived $100 \%$ of their $\mathrm{N}$ needs from four potential sources: pre-plant $\mathrm{N}\left(66 \mathrm{~kg} \cdot \mathrm{ha}^{-1}\right.$ of $\left.\mathrm{N}\right)$, plant $\mathrm{N}$ reserves, $\mathrm{N}$ available in the potting media at the time of transplanting, and $\mathrm{N}$ mineralized from the soil. Fertilized plants, in contrast, derived only $39 \%$ of their $\mathrm{N}$ from these sources and obtained the rest from $\mathrm{N}$ fertilizer applied at the beginning of the season. Interestingly, application of $\mathrm{N}$ fertilizer reduced $\mathrm{N}$ uptake from these alternative $\mathrm{N}$ sources by an average of $56 \%$. Although it is possible that the unfertilized plants were growing in a less favorable higher soil $\mathrm{pH}$ than fertilized plants, the soil $\mathrm{pH}$ in the unfertilized treatment plots was still within the acceptable range for northern highbush blueberries $(\mathrm{pH}$ less than 5.5 ). Because blueberry plant response to $\mathrm{N}$ fertilization may also be a function of soil $\mathrm{pH}$, ideally we would have had an acidified, unfertilized control in this study.

Plants fertilized with $\mathrm{N}$ also had higher $\mathrm{N}$ concentrations in each plant part and allocated more biomass to leaves and fruit than those grown without $\mathrm{N}$ fertilizer. As a result, fertilized plants lost up to nine times more $\mathrm{N}$ during leaf senescence and pruning and up to three times more $\mathrm{N}$ during fruit harvest than the unfertilized plants. By the end of the second season, total DW after pruning was similar between plants fertilized with 0 and $50 \mathrm{~kg} \cdot \mathrm{ha}^{-1}$ of $\mathrm{N}$ and lower in plants fertilized with $100 \mathrm{~kg} \cdot \mathrm{ha}^{-1}$ of $\mathrm{N}$. Total $\mathrm{N}$ content, on the other hand, was similar between plants fertilized with 0 and $100 \mathrm{~kg} \cdot \mathrm{ha}^{-1}$ of $\mathrm{N}$ and higher in plants fertilized with $50 \mathrm{~kg} \cdot \mathrm{ha}^{-1}$ of N. It is clear in this study that excessive fertilization with $\mathrm{N}$ during establishment increases plant loss and reduces growth, likely as a result of ammonium toxicity or salt stress. If we had added a control that was fertilized with added salt (e.g., sodium) to EC levels similar to those produced at the higher rates of $\mathrm{N}$ fertilization, 
we would have been able to more clearly study this aspect.

Next, we will determine the requirements of not only $\mathrm{N}$ in each plant part, but of other nutrients in the young plants and examine how the nutrient requirements were affected by the amount of $\mathrm{N}$ fertilizer applied. We will also examine uptake of fertilizer $\mathrm{N}$ and other nutrients in mature plants and eventually develop a complete nutrient budget for highbush blueberry.

\section{Literature Cited}

Bailey, J.S., A.F. Spelman, and B. Gersten. 1962. Seasonal changes in the nutrients in the leaves of Rubel blueberry bushes. Proc. Amer. Soc. Hort. Sci. 80:327-330.

Ballinger, W.E. and L.J. Kushman. 1966. Factors affecting the mineral-element content of leaves and fruit of Wolcott blueberries. Proc. Amer. Soc. Hort. Sci. 88:325-330.

Birkhold, K.T. and R.L. Darnell. 1993. Contribution of storage and currently assimilated nitrogen to vegetative and reproductive growth of rabbiteye blueberry. J. Amer. Soc. Hort. Sci. 118:101-108.

Bishop, R.F., L.R. Townsend, and D.L. Craig. 1971. Effect of source and rate of $\mathrm{N}$ and $\mathrm{Mg}$ on nutrient levels in highbush blueberry leaves and fruit. HortScience 6:37-38.

Brazelton, C. 2009. 2008 World blueberry acreage report. U.S. Highbush Blueberry Council Report. Unpublished.

Brazelton, D. and B.C. Strik. 2007. Perspective on the U.S. and global blueberry industry. J. Amer. Pom. Soc. 61:144-146.

Bryla, D.R. and R.M.A. Machado. 2011. Comparative effects of nitrogen fertigation and granular fertilizer application on growth and availability of soil nitrogen during establishment of highbush blueberry. Frontiers Crop Sci. Hort. 2:1-8.

Caruso, F.L. and D.C. Ramsdell. 1995. Compendium of blueberry and cranberry diseases. APS Press, St. Paul, MN.

Cheng, L. and R. Raba. 2009. Accumulation of macroand micronutrients and nitrogen demand-supply relationship of 'Gala'/'Malling 26' apple trees grown in sand culture. J. Amer. Soc. Hort. Sci. 134:3-13.
Clark, J.R., G.E. Fernandez, R. Maples, and B. Bordelon. 1998. Nitrogen fertilization of highbush blueberry. Ark. Expt. Sta. Res. Ser. 385:7-9.

Cummings, G.A. 1978. Plant and soil effects of fertilizer and lime applied to highbush blueberries. J. Amer. Soc. Hort. Sci. 103:302-305.

Eck, P. 1988. Blueberry science. Rutgers Univ. Press, New Brunswick, NJ.

Hanson, E.J. and J.B. Retamales. 1992. Effect of nitrogen source and timing on highbush blueberry performance. HortScience 27:12651267.

Hanson, E.J., P.A. Throop, S. Serce, J. Ravenscroft, and E.A. Paul. 2002. Comparison of nitrification rates in blueberry and forest soils. J. Amer. Soc. Hort. Sci. 127:136-142.

Hart, J., B. Strik, L. White, and W. Yang. 2006 Nutrient management for blueberries in Oregon. Ore. State Univ. Ext. Serv. Pub. EM 8918.

Hauck, R.D. and J.M. Bremner. 1976. Use of tracers of soil and fertilizer nitrogen research. Adv. Agron. 28:219-266.

Korcak, R.F. 1988. Nutrition of blueberries and other calcifuges. Hort. Rev. 10:183-227.

Ledgard, S.F. and G.S. Smith. 1992. Fate of ${ }^{15} \mathrm{~N}$ labelled nitrogen fertilizer applied to kiwifruit (Actinidia deliciosa) vines. II. Temporal changes in ${ }^{15} \mathrm{~N}$ within vines. Plant Soil 147:59-68.

Ledgard, S.F., G.S. Smith, and M.S. Sprosen. 1992. Fate of ${ }^{15} \mathrm{~N}$-labelled nitrogen fertilizer applied to kiwifruit (Actinidia deliciosa) vines. I. ${ }^{15} \mathrm{~N}$ recovery in plant and soil. Plant Soil 147:4957.

Ludwick, A.E. 1998. Western fertilizer handbook. Second horticultural edition. Calif. Fert. Assn., Interstate Publishers, Danville, IL.

Patten, K.D., E.W. Neuendorff, A.T. Leonard, and V. Haby. 1988. Mulch and irrigation placement effects on soil chemistry properties and rabbiteye blueberry plants irrigated with sodic water. J. Amer. Soc. Hort. Sci. 113:4-8.

Poonnachit, U. and R. Darnell. 2004. Effect of ammonium and nitrate on ferric chelate reductase and nitrate reductase in Vaccinium species. Ann. Bot. (Lond.) 93:399-405.

Pritts, M.P. and J.F. Hancock. 1985. Lifetime biomass partitioning and yield component relationships in the highbush blueberry, Vaccinium corymbosum L. (Ericaceae). Amer. J. Bot. $72: 446-452$.
Pritts, M.P., J.F. Hancock, and B.C. Strik. 1992. Highbush blueberry production guide. Northeastern Regional Agr. Eng. Serv., NRAES-55, Ithaca, NY.

Retamales, J.B. and E.J. Hanson. 1989. Fate of ${ }^{15} \mathrm{~N}$-labeled urea applied to mature highbush blueberries. J. Amer. Soc. Hort. Sci. 114:920923.

Retamales, J.B. and E.J. Hanson. 1990. Effect of nitrogen fertilizers on leaf and soil nitrogen levels in highbush blueberries. Commun. Soil Sci. Plant Anal. 21:2067-2078.

Strik, B., C. Brun, M. Ahmedullah, A. Antonelli, L. Askham, D. Barney, P. Bristow, G. Fisher, J. Hart, D. Havens, R. Ingham, D. Kaufman, R. Penhallegon, J. Pscheidt, B. Scheer, C. Shanks, and R. William. 1993. Highbush blueberry production. Ore. State Univ. Ext. Serv. Pub. PNW 215.

Strik, B., T. Righetti, and H. Rempel. 2006. Black plastic mulch improved the uptake of ${ }^{15}$ Nitrogen from inorganic fertilizer and organic prunings in summer-bearing red raspberry. HortScience 41:272-274.

Strik, B. and D. Yarborough. 2005. Blueberry production trends in North America, 1992 to 2003 and predictions for growth. HortTechnology 15:391-398.

Strik, B.C. and J. Hart. 1992. Fertilizer guide, blueberries. Ore. State Univ. Ext. Serv. Pub. FG 78.

Thompson, L.R. 1973. Effects of N, P, K, and Mg on the growth and productivity of the highbush blueberry. Can. J. Plant Sci. 53:161-168.

Throop, P.A. and E.J. Hanson. 1997. Effect of application date on absorption of ${ }^{15} \mathrm{~N}$ by highbush blueberry. J. Amer. Soc. Hort. Sci. 122:422-426.

Valenzuela-Estrada, L.R., V. Vera-Caraballo, L.E. Ruth, and D.M. Eissenstat. 2008. Root anatomy, morphology, and longevity among root orders in Vaccinium corymbosum (Ericaceae). Amer. J. Bot. 95:1506-1514.

Williamson, J.G. and E.P. Miller. 2009. Effects of fertilizer rate and form on vegetative growth and yield of southern highbush blueberry in pine bark culture. HortTechnology 19:152157.

Yang, W. 2002. 2001 Highbush blueberry field survey in Oregon - Cultural practices. Proc. Ore. Hort. Soc. 91:162-163. 